\title{
Relationship of Sex Type, Shift Work, Body Mass Index (BMI) and Work Loads against Work Extension in the Air Traffic Controller Operator in Makassar Sultan Hasanuddin Airport
}

\author{
Chin Hoy ${ }^{1 *}$, Lalu Muhammad Saleh ${ }^{1}$, Anwar ${ }^{2}$, Syamsiar S. Russeng ${ }^{1}$, Yahya Thamrin ${ }^{1}$, Darmawansya ${ }^{3}$ \\ ${ }^{1}$ Occupational Safety and Health Department, Faculty of Public Health, Hasanuddin University, Indonesia \\ ${ }^{2}$ Environmental Health Section, Faculty of Public Health, Hasanuddin University, Indonesia \\ ${ }^{3}$ Health Policy Administration Department, Faculty of Public Health, Hasanuddin University, Indonesia
}

DOI: $10.36348 /$ sjnhc.2020.v03i07.005

| Received: 05.07.2020 | Accepted: 24.07.2020 | Published: 28.07.2020

*Corresponding author: Chin Hoy

\section{Abstract}

Air Traffic Controller (ATC) is a service provider that regulates traffic in the air, especially airplanes to prevent planes from getting too close to each other and collisions. Increasingly crowded flight schedules the level of responsibility and workload of Air Traffic Controller (ATC) operators is increasingly numerous and this has an impact on the mental burden and fatigue felt by air traffic controller officers. This study aims to determine the sex relations, work shifts, Mass Index Body (BMI), and workload on work fatigue at the Air Traffic Controller operator at Sultan Hasanuddin Airport in Makassar. This research is a quantitative study with a cross-sectional design with a sample size of 65 people. Data were collected by conducting interviews. The instrument used was a data analysis questionnaire using the Continuity Correction test. The results of this study indicate that of the 65 respondents there was no significant relationship between sex and work fatigue $(\mathrm{p}=1,000)$, there was a relationship between work shifts and work fatigue $(p=0.015)$, there was no relationship between Body Mass Index (BMI) with fatigue $(p=0.064)$, and there is a relationship between workload and work fatigue $(p=0.021)$. The results of this study concluded that there was no relationship between sex and body mass index on fatigue and there was a relationship between work shifts and workloads at the Air Traffic Controller operator at Sultan Hasanuddin Airport in Makassar. It is expected that the Air Traffic Controller (ATC) operator should regulate and maintain the diet and intake of nutrients consumed, utilizing good rest time in between the controls so as to prevent the occurrence of errors felt by the Air Traffic Controller (ATC) operator.

Keywords: Fatigue, Air Traffic Controller, Body Mass Index, Airport.

Copyright @ 2020: This is an open-access article distributed under the terms of the Creative Commons Attribution license which permits unrestricted use, distribution, and reproduction in any medium for non-commercial use (NonCommercial, or CC-BY-NC) provided the original author and source are credited.

\section{INTRODUCTION}

Air Traffic Controller (ATC) is a service provider that regulates traffic in the air, especially airplanes to prevent planes from getting too close to each other and collisions. ATC is an air traffic regulator whose main task is to prevent planes from getting too close to one another and to avoid collisions (making separation). In addition to the separation task, the ATC is also tasked with regulating the smooth flow of traffic, assisting the pilot in handling emergencies, and providing the information needed by the pilot weather information, traffic information, navigation, and information [1].

The increasing need for air transportation by the public is increasing along with commercial and technological pressure, which of course has an impact on increasing aircraft handling activities at the airport. World flight data, if we look at the flightradar24.com online system we can see the largest online flight data with information on more than 500,000 aircraft, 150,000 flights, 7,000 airports, and 1,000 airlines, and the data is updated in real-time [2].

Based on data revealed by the International Air Transport Association (IATA) the number of requests in civil aviation continues to increase. More than seven billion passengers are estimated for 2035, this is due to an increase in the average number of passengers per year around 4.1 percent [3]. With the increase in needs requires an improvement in the aviation sector related to aspects related to flight safety and efficiency [4]. 
In Indonesia, based on data from the Central Bureau of Statistics (BPS) data in Air Transportation Statistics in the period from 2013 to 2017 scheduled national flights into the country move fluctuatively. In 2013 scheduled flights departed for 638 thousand planes. Then slightly decreased to 636 thousand planes in 2014 but rose again to 659 thousand planes in 2015 . Scheduled aircraft departures increased again to 764 thousand planes. At the end of the period, namely in 2017, the number of scheduled aircraft departures had increased to 830 thousand [5].

The density of air traffic flows makes the role of Air Traffic Controller officers in carrying out their duties requires a disciplined attitude, focus, and high responsibility. This makes the air traffic controllers have high workload consequences, and if the management does not carry out the improvement of the quality of human resource management on target, then human error can occur at any time LM Saleh [6].

Sultan Hasanuddin Airport is one of the airports in Indonesia with the busiest flight routes. Based on Flighradar24.com data, the total number of flights at the Sultan Hasanuddin Airport in Makassar reached 969 aircraft per week. This certainly has an impact on Air Traffic Controller operators whose duty as airplane traffic guides is getting more crowded flight schedules, the level of responsibility and workload of Air Traffic Controller operators is increasing and this has an impact on the mental burden and fatigue felt by airport air traffic controller officers Sultan Hasanuddin
Makassar. The purpose of this study was to determine the relationship of gender, work shifts, body mass index (BMI), and workload on work fatigue at the air traffic controller (ATC) operator Sultan Hasanuddin Makassar Airport.

\section{METHODS \\ Research design}

This type of research is an analytic survey using a cross-sectional study design. This research was conducted at Makassar Sultan Hasanuddin Airport.

\section{Population and sample}

The population used in this research is 184 Air Traffic Controller operators in Sultan Hasanuddin Airport Makassar. And the sample in this study based on the Slovin formula as many as 65 people.

\section{Data collection}

Data collection is done through questionnaires and measurements. Data on gender, work shifts, body mass index (BMI), and workload were obtained through interviews with air traffic controller (ATC) operators.

\section{Data analysis}

The data obtained were analyzed using a computer application where univariate and bivariate analysis used SPSS 25 for Windows to determine ranking, frequency distribution, and the relationship between dependent variables and independent variables.

\section{RESULTS}

Table-1: Frequency Distribution of Work Periods, Work Shifts, Workloads and Fatigue in Air Traffic Controller Operators at Sultan Hasanuddin Airport in Makassar

\begin{tabular}{|l|l|c|c|}
\hline \multicolumn{1}{|c|}{ Variable } & Category & Frequency & Percentage (\%) \\
\hline Sex & Female & 16 & 24,6 \\
& Male & 49 & 75,4 \\
& Total & $\mathbf{6 5}$ & $\mathbf{1 0 0}$ \\
\hline Work Shift & Night & 13 & 20,0 \\
& Day & 52 & 80,0 \\
\hline \multirow{2}{*}{ Body Mass Index (BMI) } & Total & $\mathbf{6 5}$ & $\mathbf{1 0 0}$ \\
& Abnormal & 21 & 32,3 \\
& Normal & 44 & 67,7 \\
\hline \multirow{2}{*}{ Workload } & Total & $\mathbf{6 5}$ & $\mathbf{1 0 0}$ \\
& Heavy & 37 & 56,9 \\
& Light & 28 & 43,1 \\
\hline Work Fatigue & Total & $\mathbf{6 5}$ & $\mathbf{1 0 0}$ \\
& Tired & 28 & 43,1 \\
& Not tired & 37 & 56,9 \\
\hline & Total & $\mathbf{6 5}$ & $\mathbf{1 0 0}$ \\
\hline
\end{tabular}

The frequency distribution in Table 1 shows that of 65 air traffic controller operators who experienced fatigue as many as $28(43.1 \%)$ and who did not experience fatigue as much as $37(56.9 \%)$. Based on the sex of respondents who were female as many as 16 $(24.6 \%)$ and those who were male were 49 (75.4\%).
And air traffic controller (ATC) operators working on night shifts are 13 people $(20.0 \%)$. And those working on the afternoon shift were 52 people $(80.0 \%)$, and Respondents who had an abnormal body mass index were $21(32.3 \%)$, and those who had a normal body mass index were $44(67.3 \%)$. And respondents who 
have heavy workloads as many as 37 people (56.9\%).

And those who have light workloads are 28 people
$(43.1 \%)$.

Table-2: Relationship between Gender and Work Fatigue in the Air Traffic Controller Operator at Sultan Hasanuddin Airport in Makassar

\begin{tabular}{|c|c|c|c|c|c|c|c|}
\hline \multirow{3}{*}{ Sex } & \multicolumn{4}{|c|}{ Work Fatigue } & \multicolumn{2}{c|}{ Total } & \multirow{2}{*}{$\begin{array}{c}\text { Statistical } \\
\text { Test Result }\end{array}$} \\
\cline { 2 - 6 } & \multicolumn{2}{|c|}{ Tired } & \multicolumn{2}{c|}{ Not Tired } & \multicolumn{2}{c}{} & \\
\cline { 2 - 6 } & $\mathrm{n}$ & $\%$ & $\mathrm{n}$ & $\%$ & $\mathrm{n}$ & $\%$ & \multirow{2}{*}{$\boldsymbol{p = 1 , 0 0 0}$} \\
\hline Female & 7 & 43,8 & 9 & 56,2 & 16 & 100 & \\
\hline Male & 21 & 42,8 & 28 & 57,2 & 49 & 100 & \\
\hline \multicolumn{1}{|c|}{ Total } & $\mathbf{2 8}$ & & $\mathbf{3 7}$ & & $\mathbf{6 5}$ & & \\
\hline
\end{tabular}

Bivariate analysis of table 2 shows that from a total of 65 operators of air traffic controller (ATC) operators at the Sultan Hasanuddin Airport in Makassar, based on the sex of work fatigue more experienced by respondents who were male as many as 21 people $(42.8 \%)$, while in the female sex who experienced fatigue as many as 7 people $(43.8 \%)$. The results of data analysis using the Chi-Square test obtained the value of $p=1,000$ ( $p>0.05)$. It was concluded that gender did not have a significant relationship with work fatigue at the Air Traffic Controller operator at the Sultan Hasanuddin Airport in Makassar.

Table-3: Relationship between Work Shift and Work Fatigue at the Air Traffic Controller Operator at Sultan Hasanuddin Airport in Makassar

\begin{tabular}{|c|c|c|c|c|c|c|c|}
\hline \multirow{2}{*}{ Work Shift } & \multicolumn{4}{|c|}{ Work Fatigue } & \multicolumn{2}{c|}{ Total } & \multirow{2}{*}{$\begin{array}{c}\text { Statistical } \\
\text { Test Result }\end{array}$} \\
\cline { 2 - 6 } & \multicolumn{2}{|c|}{ Tired } & \multicolumn{2}{c|}{ Not Tired } & \multicolumn{2}{|c|}{} \\
\cline { 2 - 6 } & $\mathrm{n}$ & $\%$ & $\mathrm{n}$ & $\%$ & $\mathrm{n}$ & $\%$ & \\
\hline Night & 10 & 76,9 & 3 & 23,1 & 13 & 100 & \multirow{2}{*}{$=\mathbf{0 , 0 1 5}$} \\
\hline Day & 18 & 34,6 & 34 & 65,4 & 52 & 100 & \\
\hline Total & $\mathbf{2 8}$ & & $\mathbf{3 7}$ & & $\mathbf{6 5}$ & & \\
\hline
\end{tabular}

Bivariate analysis of table 3 shows that from a total of 65 operators of air traffic controller (ATC) operators at the Sultan Hasanuddin Airport in Makassar, based on work shifts, it showed that work fatigue was more experienced by respondents who worked at night shifts, namely 10 people $(76.9 \%)$, while in the afternoon shift that experienced fatigue that was 18 people $(34.6 \%)$. The results of data analysis using the Chi-Square test obtained the value of $\mathrm{p}=0.015$ ( $\mathrm{p}$ $<0.05$ ), this shows the work shift has a significant relationship with work fatigue at the Air Traffic Controller operator at the Sultan Hasanuddin airport in Makassar.

Table-4: Relationship between Body Mass Index (BMI) and Work Fatigue at the Air Traffic Controller Operator at Sultan Hasanuddin Airport in Makassar

\begin{tabular}{|c|c|c|c|c|c|c|c|}
\hline \multirow{2}{*}{ BMI } & \multicolumn{4}{|c|}{ Work Fatigue } & \multicolumn{2}{c|}{ Total } & \multirow{2}{*}{$\begin{array}{c}\text { Statistical } \\
\text { Test Result }\end{array}$} \\
\cline { 2 - 7 } & \multicolumn{2}{|c|}{ Tired } & \multicolumn{2}{c|}{ Not Tired } & \multicolumn{2}{c|}{} & \\
\cline { 2 - 7 } Abnormal & $\mathrm{n}$ & $\%$ & $\mathrm{n}$ & $\%$ & $\mathrm{n}$ & $\%$ & \\
\hline Normal & 13 & 61,9 & 8 & 38,1 & 21 & 100 & \\
\hline Total & & & & & & & \\
\hline
\end{tabular}

Bivariate analysis of table 4 shows that from a total of 65 operators of air traffic controller (ATC) operators at Sultan Hasanuddin Airport in Makassar, based on body mass index (BMI) work fatigue is more experienced by respondents who have abnormal BMIs as many as 13 people (61.9\%), while the normal BMI who experienced fatigue were 15 people $(34.1 \%)$. The results of data analysis using the Chi-Square test obtained the value of $p=0.064(p<0.05)$. This shows that body mass index (BMI) does not have a significant relationship with work fatigue at the Air Traffic Controller operator at Sultan Hasanuddin Airport in Makassar. 
Table-5: Relationship between Workload and Work Fatigue in the Air Traffic Controller Operator at Sultan Hasanuddin Airport in Makassar

\begin{tabular}{|c|c|c|c|c|c|c|c|}
\hline \multirow[t]{3}{*}{ Workload } & \multicolumn{4}{|c|}{ Work Fatigue } & \multirow{2}{*}{\multicolumn{2}{|c|}{ Total }} & \multirow{3}{*}{$\begin{array}{c}\text { Statistical } \\
\text { Test Result }\end{array}$} \\
\hline & \multicolumn{2}{|c|}{ Lelah } & \multicolumn{2}{|c|}{ Tidak Lelah } & & & \\
\hline & $\mathrm{n}$ & $\%$ & $\mathrm{n}$ & $\%$ & $\mathrm{n}$ & $\%$ & \\
\hline Berat & 21 & 56,8 & 16 & 43,2 & 37 & 100 & $p=0,021$ \\
\hline Ringan & 7 & 25,0 & 21 & 75,0 & 28 & 100 & \\
\hline Total & 28 & & 37 & & 65 & & \\
\hline
\end{tabular}

Bivariate analysis of table 5 shows that from a total of 65 operators of air traffic controller (ATC) operators at the Sultan Hasanuddin Airport in Makassar, based on workloads, work fatigue was more experienced by respondents who had heavy workloads of 21 people $(56.8 \%)$, whereas in the light category of workload experiencing fatigue that is as many as 7 people $(25.0 \%)$. The results of data analysis using the Chi-Square test obtained the value of $\mathrm{p}=0.021$ ( $\mathrm{p}$ $<0.05$ ), this shows that workload has a significant relationship with work fatigue at the Air Traffic Controller operator at Sultan Hasanuddin Airport in Makassar.

\section{DISCUSSION}

In this study, gender did not have a significant relationship to work fatigue at the air traffic controller operator at Sultan Hasanuddin Airport in Makassar. This research is in line with research conducted by [7] the ATC Tower Control Juanda International Airport which states that there is no relationship between sex with fatigue felt by the Air Traffic Controller operator. This can be because the company has anticipated it because the number of Air Traffic Controller (ATC) officers is mostly male, which has a greater proportion compared to those of female sex.

In this study, the air traffic control operator that experienced the most fatigue was the air traffic controller operator which was female, which was 7 $(43.7 \%)$ because it was generally caused by women only having physical strength $2 / 3$ of physical ability or muscle strength men, but in certain cases women are more thorough than men. Men are physically stronger than women. Physically, stronger muscles provide better workability than weaker ones. In addition, women workers also still have a share of their family and household Saleh and Rachmat [8].

But different research conducted by [9] with the title "The Effect of Individual Characteristics and Work Attitudes Toward Atc Fatigue At the Airport" the results of the study showed a significant level of 0.04 $(<0.05)$, so there was an effect of sex on fatigue. This is due to a higher percentage of women's body fat and lower blood $\mathrm{Hb}$ levels than men, so women tend to feel tired more quickly than men.

The results of this study also showed that work shifts had a significant relationship with work fatigue at the Air Traffic Controller operator at Sultan Hasanuddin Airport in Makassar. This study is in line with research conducted by Wang and Ke [10] that the shift work system on ATC has a relationship with the high prevalence of fatigue. In this study, the most experienced fatigue experienced by ATC operators who work on the night shift as many as 10 people (76.9\%) this is caused by working on the night shift will disrupt the circadian rhythm by working when the body should be in time to rest which will increase the tendency risk for experiencing fatigue [11]. Night shifts also have negative effects related to sleep cycles, are able to cause drowsiness, performance, and risk of accidents Saleh, Russeng et al. [12].

This study also showed that body mass index did not have a significant relationship with work fatigue at the Air Traffic Controller operator at Sultan Hasanuddin Airport in Makassar. The results of this study are in line with those stated by [12] There is no significant relationship between nutritional status (hemoglobin, hematocrit, serum ferritin, and BMI) with work fatigue, this is evident from the values. this is possible because the body mass index in this study was measured by a body mass index with long-term nutritional intake parameters, while daily nutritional intake associated with fatigue at the time of the study determined the amount of energy needed on that day.

Health nutritional status and work power are closely related to a person's nutritional level, the body needs substances from food for body maintenance, repair of cell and tissue damage. These nutrients are also needed for work and increase commensurate with the weight of the work [13]. In this study, fatigue experienced by workers who have an abnormal body mass index is caused by workers who have fat nutritional status will experience fatigue more quickly because there is excessive fat in the worker's organs or the accumulation of fat and when doing work will more limited due to obstacles in moving [14].

The results of this study also show the results of data analysis using the Chi-Square test that workload has a significant relationship with work fatigue at the Air Traffic Controller operator at Sultan Hasanud airport in Makassar. The results of this study are in line with research put forward by Dewi [10] that workloads that are too excessive or too little can cause interference or illness due to work. Excessive workload can cause physical and mental fatigue and emotional reactions such as headaches, indigestion, and irritability. While the workload is too little where the work that occurs due to the repetition of motion will cause boredom. 
In this study, shows that more work fatigue is experienced by respondents who have a heavy workload. That is because the ATC profession requires concentration, calculations, estimates, and good imagination and ATC is required to have the speed and accuracy to process the information obtained in making the right decision to avoid accidents. In this case, it can be concluded that the controllers must always have a high concentration and must be able to make calculations, estimates, and imagine the aircraft being controlled [9].

The main responsibility that must be owned by the air traffic controller (ATC) operator is to ensure the safety of the aircraft and all crew and passengers. This causes the ATC workload to be higher. Because it is demanded to have a high concentration in managing, supervising, and controlling the aircraft, so that the supervised flight avoids accidental incidents on land and in the air plus situations and environments that can be said to be isolated [13-16].

\section{CONCLUSION}

Based on the results of this study, it can be concluded that gender and body mass index does not have a significant relationship to fatigue in air traffic controller (ATC) operators and work shifts and workload has a significant relationship to work fatigue in air traffic controller (ATC) operators at the Sultan Hasanuddin airport in Makassar. It is expected that the air traffic controller (ATC) operator should regulate and maintain the diet and intake of nutrients consumed, utilizing good rest time in between the controls so as to prevent the occurrence of errors felt by the air traffic controller (ATC) operator.

\section{REFERENCES}

1. Prasetyo, A. D., \& Budiawan, W. (2019). Studi Stres Kerja Operator Air Traffic Control (ATC) Pada Bandara Ahmad Yani Semarang. Industrial Engineering Online Journal, 7(4).

2. Saleh, L. M. (2018). Behind The Scene Aviation Safety. Yogyakarta, Deepublish.

3. International Air Transport Association (IATA). (2015). Airport Expansion: Bright Thinking.

4. Lovato, A. V., Fontes, C. H., Embiruçu, M., \& Kalid, R. (2018). A fuzzy modeling approach to optimize control and decision making in conflict management in air traffic control. Computers \& Industrial Engineering, 115, 167-189.
5. Central Bureau of Statistics. (2017). Air Transportation Statistics. Jakarta: BPS Statistik Indonesia.

6. Saleh, L. M. (2018). Tingkat Risiko Psikologis Karyawan ATC di Salah Satu Cabang Air NAV Indonesia. Media Kesehatan Masyarakat Indonesia Universitas Hasanuddin, 14(4), 345-350.

7. Hakim (2011). Gambaran Tingkat Kelelahan Pada Petugas Tower Control Air Traffic Controller (ATC) di Bandara Internasional Juanda. Surabaya: Univeristas Airlangga.

8. Jati, I. W., Rosydah, B. M., \& Rachman, F. (2018). Pengaruh Karateristik Individu Dan Sikap Kerja Terhadap Kelelahan ATC Di Bandara. In Seminar K3 (Vol. 2, No. 1, pp. 519-524).

9. Prakoso, P. S., Nurfadhilah, S., \& Rochmawati, L. (2018). Pengaruh Beban Kerja Air Traffic Controller Terhadap Stres Kerja Di Bandar Udara Internasional Juanda. Approach: Jurnal Teknologi Penerbangan, 2(2), 20-28.

10. Wang, T. C., \& Ke, G. C. (2013). Fatigue minimization work shift scheduling for air traffic controllers. International Journal of Automation and Smart Technology, 3(2), 91-99.

11. Sharfina, N. P. (2016). Analisis Faktor-Faktor Risiko Yang Berhubungan Dengan Kelelahan Pada Petugas Air Traffic Controller (ATC) Unit Tower Control Di Jakarta Air Traffic Services Center (JATSC) Bandara Internasional Soekarno-Hatta Tangerang Tahun 2016. Fakultas Kesehatan Masyarakat. Jakarta: Universitas Indonesia.

12. Russeng, S. S. (2015). Nutritional Status and Work Fatigue (Study at Night Bus Drivers in South and West Sulawesi). International Journal of Sciences: Basic and Applied Research (IJSBAR), 20(1), 90101.

13. Saleh, L. M., Russeng, S. S., \& Rahim, M. R. (2020). The effect of progressive muscle relaxation on decreasing work stress in air traffic controller. Enfermería Clínica, 30, 231-235.

14. Pranoto, A. B. (2014). Hubungan Status Gizi Dengan Kelelahan Kerja Pada Tenaga Kerja Bagian Weaving di PT. Iskandar Indah Printing Textile Surakarta. Doctoral dissertation, Universitas Muhammadiyah Surakarta.

15. Saleh, L. M., \& Rachmat, M. (2019). Safety Performance in Air Traffic Controller (ATC) Bali Indonesia. ICER-PH.

16. Saleh, L. M. (2019). Teknik Relaksasi Otot Progresif Pada Air Traffic Controller (ATC). Deepublish. 